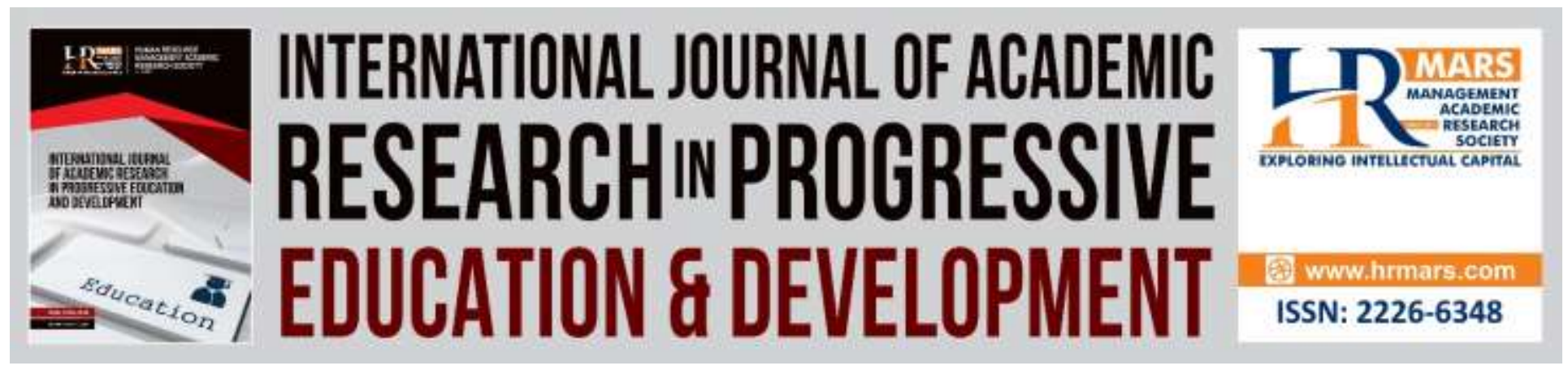

\title{
Attitude of Special Education Teachers in Teaching Special Education Integration Program towards Learning Disabilities Students Dyslexia Academic Performances in Distrıct Hilir Perak, Perak
}

Md. Nasir Bin Masran, Sangeetha Lachumy A/P Sengiah, Rosmanirah Othman \& Nur Fittrah Hassan

To Link this Article: http://dx.doi.org/10.6007/IJARPED/v8-i4/6913

DOI:10.6007/IJARPED/v8-i4/6913

Received: 15 October 2019, Revised: 30 October 2019, Accepted: 11 November 2019

Published Online: 30 November 2019

In-Text Citation: (Masran et al., 2019)

To Cite this Article: Masran, M. N. Bin, Sengiah, S. L. A., Othman, R., \& Hassan, N. F. (2019). Attitude of Special Education Teachers In Teaching Special Education Integration Program Towards Learning Disabilities Students Dyslexia Academic Performances In Distrıct Hilir Perak, Perak. International Journal of Academic Research in Progressive Education and Development, 8(4), 1132-1142.

Copyright: (C) 2019 The Author(s)

Published by Human Resource Management Academic Research Society (www.hrmars.com)

This article is published under the Creative Commons Attribution (CC BY 4.0) license. Anyone may reproduce, distribute, translate and create derivative works of this article (for both commercial and non-commercial purposes), subject to full attribution to the original publication and authors. The full terms of this license may be seen at: http://creativecommons.org/licences/by/4.0/legalcode

Vol. 8(4) 2019, Pg. 1132 - 1142

http://hrmars.com/index.php/pages/detail/IJARPED JOURNAL HOMEPAGE

Full Terms \& Conditions of access and use can be found at http://hrmars.com/index.php/pages/detail/publication-ethics 


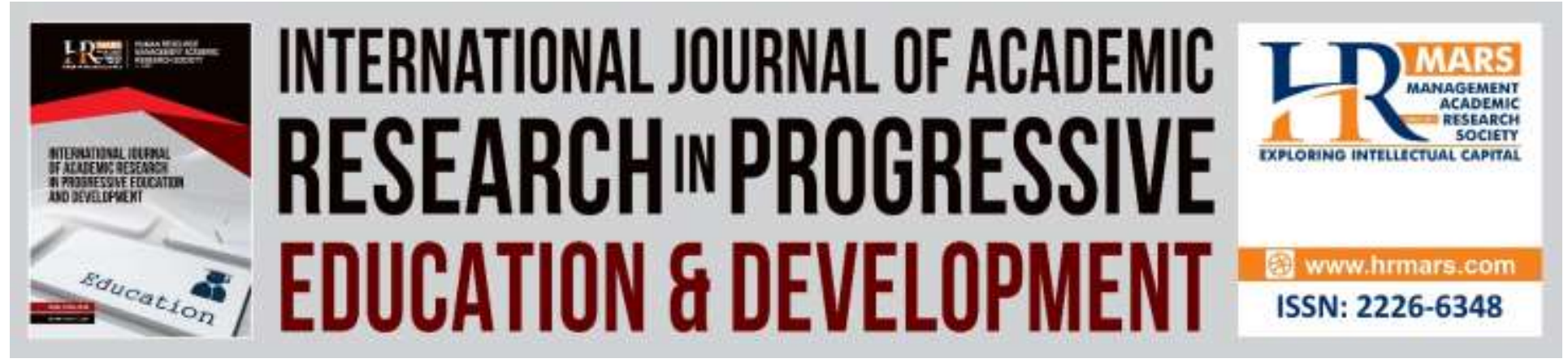

\title{
Attitude of Special Education Teachers in Teaching Special Education Integration Program towards Learning Disabilities Students Dyslexia Academic Performances in Distrıct Hilir Perak, Perak
}

\author{
Md. Nasir Bin Masran, Sangeetha Lachumy A/P Sengiah, \\ Rosmanirah Othman \& Nur Fittrah Hassan \\ Faculty of Human Development, Sultan Idris Education University, MALAYSIA
}

\begin{abstract}
This study aimed to review the attitude of Special Education Teachers in PPKI on academic performance dyslexia students in district Hilir Perak, Perak. This study used a survey method using a questionnaire which is divided into three parts. Part A concerns with teacher's personal information and Section $B$ is about the attitude of teacher and Part $C$ is on the academic performance of students. The sample consisted of 69 teachers around the district of Hilir Perak. Data were analysed using descriptive statistics and statistical inference. T-test and one way ANOVA was used to analyse the research questions are built. The findings showed that demographic factors such as gender, level of education and teaching time showed a significant difference to the level of teacher attitude. Meanwhile, age, length of service and marital status did not show significant differences in the levels of attitude. In addition, correlation tests were also carried out to identify the relationship between the attitudes of special education teachers on the academic performance of Dyslexia students. The findings of the test results showed a correlation coefficient of $r=.418 \mathrm{sig}=0.004$ where $<.05$. In conclusion there is a correlation between the attitudes of teachers of special education pupils to academic performance Dyslexia. The positive coefficient $r$ indicates the positive attitude of teachers of special education, the higher the academic achievement of Dyslexia students. The findings also suggest that future studies will help improve the academic performance of Dyslexia students and taking into account the attitude and precision of special education teachers.
\end{abstract}

Keywords: Commitment, Special Education Integration Program (PKKI), Academic Performance, Students Dyslexia

\section{Introduction}

The National Education Policy has long intended for students to develop themselves in terms of their intellect, spirituality, physicality and social aspect. That said, some students are to be 
categorised under special students. Special Education is a type of teaching that is designed to fulfill special needs of children with special ability and knowledge (Talib, 2006; Abdullah, Daud, Ariff, \& Shaifuddin, 2018; Tyasari, Yusof, Bahador, 2018). Acocrding to Heward (2000) special education can be explained from various perspectives. Special education as intervention entails the processes of preventing, eliminating or overcoming the barriers that have prevented students from taking part actively in school or in the community.

Based on 1996 Special Education Act, Program Special education Integrasi (PPKI) or Integrated Special Education Program was introduced. This is an education program for special education students where it is only attended by students with special needs in special classes at government or government-aided schools.

Kategori Murid Keperluan Khusus (MBK) or Special Needs Students Category, those who have to follow the program and special education service are those who experience mental retardation, learning disabilities, emotional and behavioral disorder, communication - speech and language disorder, hearing loss, blindnees or low vision, physical impairments and giftedness.

1996 Special Education Act states that special needs students require special teachers for them. Murid bermasalah merupakan kanak-kanak yang telah dikenal pasti dan disahkan oleh pakar profesional klinikal sebagai mengalami kecacatan yang menganggu proses pembelajaran.

Teachers teaching, guiding, chiding, praising, persuading and scolding students are common in classrooms. In these situations, different qualities will tend to emerge. According to Atan Long (1992) in his book Managing Students' Behaviour, there are several characteristics of a good teacher namely having stable and healthy emotions and mental, being trustworthy, always giving cooperation, having good health and mental health and having a polite and pleasant behaviour.

According to 1996 Special education Act, special education teachers must use the Special Education Curriculum. They can also modify it to suit the method or technique of teaching and learning, the time allocated for every activity, activity arrangement and teaching aids. Teachers' determination in influencing students' achievement refers to the teachers' self-confidence, (Bandura,1997).

According to Mohamed (2005) the teaching should lean on the sharing of experience and commitment so that it will involve all students actively and they also have the responsibility to plan and organise activities to give learning experience to students, enabling them to think about the concept and process of teaching and learning.

Teacher's attitude in implementing meaningful teaching tasks means that there is high determination for teachers to instil effective pedagogical strategies towards influencing students' learning achievement.

\section{Problem Statement}

According to Mohamed (2005), students with learning problems can be figured out from the aspects of psychomotor, cognitive and affective. Erma et al. (2014) state that the close relationship between teachers and students plays an important role in determining students' interests towards the lessons taught and it also influences teachers to choose teaching strategies that are engaging and can increase the commitment of their students towards the lesson. 
Mohamad (2009) states that students' excellence is very important in producing more labour that is competitive, in line with the national vision to become a developed country as we approach the year 2020. The expansion of access to quality system education can open up more opportunities to Malaysians to increase their status of living. High efficacy in the education system will only materialise by ensuring that all schools deliver high quality education and skills to each and every child.

As teachers, this group is held accountable in carrying out teaching and learning activity also giving the same degree of commitment to all students. Therefore, teacher is a significant factor in influencing the interest and commitment of students towards their lessons and they have the potential to change students' attitude and status towards a particular curriculum. (Salleh 2003; Hattie 2003). Public concern towards the teaching quality as proposed in the statement issued by School Inspectorate (Sekolah 2001, 24) must be given serious attention by all educationists as it will give a clear picture of the role of the teacher in achieving the aims of national education.

Teachers will always face the weaknesses and shortcomings of their students. However, quality teachers will not make a big deal of these, and instead will pay attention to the students' positive behaviour and use the strengths to engage their students. Fredriksen and Rhodes (2004) state that the relationship between teacher and students can leave an impact on student learning and their academic achievement. Fleisher (2005) also opines that this close relationship between both parties play an important role in determining students' interests and boost their commitment towards their lessons.

\section{Study Objective}

The study objectives as follows:

a) To identify the difference between gender and the attitude of special education teachers towards the academic performance of dyslexic students.

b) To identify the difference between age and attitude of special education teachers towards dyslexic students' academic performance.

c) To identify the difference between marital status and attitude of special education teachers towards dyslexic students' academic performance.

d) To identify the difference between academic achievement and special education teachers' attitude towards dyslexic students' academic performance.

e) To identify the difference between tenure and special education teachers' attitude towards dyslexic students' academic performance.

f) To identify the difference between teaching period and special education teachers' attitude towards dyslexic students' academic performance.

g) To identify the difference between Special Education Teacher's Attitude With Dyslexic Students' Academic Performance.

\section{Study Question}

a) Is there any difference between gender and the attitude of special education teachers towards the academic performance of dyslexic students? 
Vol. 8, No. 4, 2019, E-ISSN: 2226-6348@ 2019 HRMARS

b) Is there any difference between age and attitude of special education teachers towards dyslexic students' academic performance?

c) Is there any difference between marital status and attitude of special education teachers towards dyslexic students' academic performance?

d) Is there any difference between academic achievement and special education teachers' attitude towards dyslexic students' academic performance?

e) Is there any difference between tenure and special education teachers' attitude towards dyslexic students' academic performance?

f) Is there any difference between teaching period and special education teachers' attitude towards dyslexic students' academic performance?

g) Is there any difference between Special Education Teacher's Attitude With Dyslexic Students' Academic Performance?

\section{Study Methodology}

\section{Study Limitation}

This study has some limitations. The limitations include the location, the study sample and the factor being studied. The feedback given by the teachers in this study is assumed to have been given honestly and with a sense of responsibility.

\section{Study Design}

In this current work, the approcah that will be employed will be quantitative, where reference will be made to descriptive approach. Descriptive research will explain the state or phenomenon that occurs frequently in research.

Next, data collection method in the form of questionnaires is a quantitative study. The strength of this method is that researcher can make a generalisation or inference about the parameter of the population based on the sample statisctics used in a study. Apart from that, for the group as a whole, we can make a general conclusion towards part of the population based on the study done. Survey has become the mainstay of the study design. Through the survey and sampling involving small and detailed elements, a lot of information can be recorded and gathered.

\section{Sampling}

Researchers choose 17 Special education Integrated Schools including primary and secondary schools as the place of study located in Hilir Perak, Perak. This district is said to be one of the districts from 11 districts located in Perak. Its city is Teluk Intan. 69 special education teachers involved in this study constitute the study population from a total of 85 special education teachers. The sample is chosen conveniently in this study for every school in the district of Hilir Perak. To determine the non-uniform teacher group in terms of ethnicity and qualification, the easy random sampling is used. In this study, the District Office in Hilir Perak had provided the information about the number of special education teachers involved. 
Vol. 8, No. 4, 2019, E-ISSN: 2226-6348@ 2019 HRMARS

\section{Study Instrument}

This study is in the form of quantitative survey, thus the questionnaire form is used as the main instrument because it is easier and more effective (Najib, 2003; (Usaini \& Abubakar, 2015). This study used a survey method using a questionnaire which is divided into three parts. Part $A$ concerns with teacher's personal information and Section $B$ is about the attitude of teacher and Part $\mathrm{C}$ is on the academic performance of students.

\section{Study Finding}

Statistical Package For The Social Science (SPSS) is used to process the data thatis gathered to see teachers' behaviour in Primary and Secondary Special education Integrated Schools towards dyslexic students' academic performance. Next, T-Test, Pearson Correlation, Spearmen Rho and one-way ANOVA were adopted to analyse the data based on study questions. The frequency analysis was also determined to get the percentage, frequency, mean and middle value. The correlation method was adopted in this study to identify the relationship and teacher's attitude among special education teachers towards the academic performance of students with dyslexic learning problems.

Based on the statistical analysis, items 13, 31 and 35 are items with high mean scores. These three items test respondents about their attitude towards dyslexic students. Meanwhile, item 23 is the item with low mean score. It asks about the relationship between respondents and students in a special education program and it reveals that the relationship is not very close. Thus, almost all respondents have chosen scale 1 and 2 only meaning disagree and quite disagree. In the descriptive analysis, a total of 69 respondents have taken part in this study. It is explained in detail here about the background of the respondents - it includes gender, age information, marital status, highest education level,teaching time and tenure.

Ho (1): There is no significant difference between gender and the attitude of special education teachers towards the academic performance of dyslexic students.

Table 1: Teachers' attitude based on gender

\begin{tabular}{ccccccc}
\hline Gender & N & Mean & SD & t-value & Df & Sig \\
\hline Male & 29 & 3.3148 & 0.11177 & -4.076 & 43 & \\
Female & 40 & 3.7704 & 0.15161 & -3.005 & & 0.000 \\
\hline
\end{tabular}

From the t-test conducted, there is a null hypotheis stating that there is no significant difference between gender and the attitude of special education teachers towards dyslexic students' academic performance. However, the finding shows that the $\mathrm{N}$ value for male is 29 and the $\mathrm{N}$ value for female is 40 with the respective mean value of 3.3148 and 3.7704 . The $\mathrm{t}$-value is $-4.076,-3.005$ with the degree of freedom 43. P-value $=0.000$ which is $<0.05$. The test shows that there is a significant difference between gender and the attitude of special education teachers towards dyslexic students' academic performance. The t-test is the significance that is put to the test. In sum, the null hypothesis is rejected because there is no significant difference between gender and the teacher's attitude towards their dyslexic students' academic performance. 
Vol. 8, No. 4, 2019, E-ISSN: 2226-6348 @ 2019 HRMARS

Ho (2): There is no significant difference between age and attitude of special education teachers towards dyslexic students' academic performance.

Table 2: Teacher's attitude and age

\begin{tabular}{ccccc}
\hline Age Group & Df & Min & F & P \\
\hline Inter-Group & 3 & 1.059 & 11.703 & .000 \\
In Group & 41 & .090 & & \\
\hline Total & 44 & & & \\
\hline
\end{tabular}

Based on the table above, the F-value is 11.703 and the mean value is 1.059 Inter-Group. The mean value for In group is .090 . P-value $=0.000(<.05)$ proving that there is a significant difference between age and attitude of special education teachers towards dyslexic students' academic performance. Thus, the null hypothesis is also rejected with the assumption that age can be the determinant to the attitude of special education teachers towards the dyslexic students' academic performance.

Ho (3): There is no significant difference between marital status and attitude of special education teachers towards dyslexic students' academic performance.

Table 3: Teacher's attitude and marital status

\begin{tabular}{ccccc}
\hline Age Group & Df & Min & F & P \\
\hline Inter-Group & 3 & .061 & .373 & .773 \\
In group & 41 & .163 & & \\
\hline Total & 44 & & & \\
\hline
\end{tabular}

Based on the table above, the $\mathrm{F}$ value is .373 with the mean value .061 Inter-Group. The mean value In group is .163. Next, the $p$ value is 0.773 (>.05). This shows that there is no significant difference between marital status and special education teachers' attitude towards dyslexic students' academic performance. Thus, the null hypothesis fails to be rejected. This indicates that marital status is not a determinant to special education teachers' attitude towards the academic performance of dyslexic students.

Ho (4): There is no significant difference between academic achievement and special education teachers' attitude towards dyslexic students' academic performance.

Table 4: Teacher's attitude and academic qualifications

\begin{tabular}{ccccc}
\hline Age Group & Df & Min & F & P \\
\hline Inter-Group & 2 & .251 & 1.653 & .204 \\
In group & 42 & .152 & & \\
\hline Total & 44 & & & \\
\hline
\end{tabular}

Referring to the table above inter-Group of the $F$ value $=1.653$ with the mean value .251 and the in group mean value .152. The $p$ value is $0.204(>.05)$. This proves that there is no significant difference between academic qualification and Special education teachers' attitude towards dyslexic students' academic performance. Thus the null hypothesis fails to be rejected and it is assumed that academic performance is not a determinant to special education teachers' attitude towards dyslexic students' academic performance. 
Vol. 8, No. 4, 2019, E-ISSN: 2226-6348 @ 2019 HRMARS

Ho (5): There is no significant difference between tenure and special education teachers' attitude towards dyslexic students' academic performance.

Table 5: Teacher's attitude and tenure

\begin{tabular}{ccccc}
\hline Age Group & Df & Min & F & P \\
\hline Inter-Group & 3 & .695 & 5.936 & .002 \\
In group & 41 & .117 & & \\
\hline Total & 44 & & & \\
\hline
\end{tabular}

According to the table above, the $F$ value is 5.936 with the mean value .695 Inter-Group. Meanwhile, the mean value for In group is .117. The $p$ value is $0.002(<.05)$. This reveals that there is a significant difference between tenure and special education teachers' attitude towards dyslexic students' academic performance. Thus, the null hypothesis is rejected with the assumption that the tenure is a determinat to the teachers' attitude towards the dyslexic students' academic performance.

Ho (6): There is no significant difference between teaching period and special education teachers' attitude towards dyslexic students' academic performance.

Table 6: Teacher's attitude and teaching period

\begin{tabular}{ccccc}
\hline Teaching Time/Period & Df & Min & F & P \\
\hline Inter-Group & 3 & 0.068 & 0.420 & .739 \\
In group & 41 & 0.163 & & \\
\hline Total & 44 & & & \\
\hline
\end{tabular}

Based on the table above, it shows that the Inter-Group of the $F$ value is 0.420 with the mean value of 0.068 and the mean value in group is 0.163 . The $p$ value $=0.739(>0.05)$. It proves that there is no significant difference between teaching period and the teachers' attitude towards their dyslexic students. Thus, the null hypothesis fails to be rejected with the assumption that the teaching period is not a determinant to the special education teachers' attitude towards dyslexic students' academic performance.

Ho (7): There is a significant difference between Special Education Teacher's Attitude With Dyslexic Students' Academic Performance.

Table 7: Correlation Of Special Education Teacher's Attitude With Dyslexic Students' Academic Performance.

\begin{tabular}{cccc}
\hline & & Academic \\
Attitude & Pearson & 1 & $\begin{array}{c}\text { Acalte } \\
\text { Performance }\end{array}$ \\
\hline & Correlation & & $.418^{* *}$ \\
& Sig. (2-tailed) & 69 & .004 \\
Academic Performance & $\mathrm{N}$ & 69 & 1 \\
& Pearson & $.418^{* *}$ & \\
& Correlation & & 69 \\
& Sig. (2-tailed) & .004 & 69 \\
\hline
\end{tabular}


To identify the relationship between the attitude of special education teachers and dyslexic students' academic performance, the correlation test is carried out. As the outcome of the test, the correlation coefficient shows that $r=.418$ with the sig value 0.004 where $<.05$. Thus, the study' alternative hypothesis cannot be rejected. Thus, a conclusion can be made that there is a significant difference between the teachers' attitude and the academic performance of students suffering from dyslexia. Here, the positive $r$ coefficient value demonstrates that the more positive the attitude of the teachers, the better academic performance is shown by the dyslexic students.

\section{Conclusion for the Study Outcome}

Eighty five questionnaire forms were distributed an sixty questionnaires were successfullt compiled for the data analysis. According to the table above, in this study, 69 PPKI teachers had taken part as the respondents. From that, 29 are male or by percentage $42.0 \%$. Meanwhile, 40 are female, or $58.0 \%$.

According to the analysis, four null hypotheses are acceptable and three more had been rejected. The findings show that the demographic factors like marital status, teaching period in a weel and academic qualifications do not show any significant difference with the attitude of special education teachers towards the dyslexic students' academic performance. Next, the next demographic factors like age, gender, tenure show a significant difference towards the teachers' attitude in handling dyslexic students.

All in all, the mean of the items are 3.317. Based on the Likert scale, the relationship stays at Agree level. By contrast, a low mean value is 1.4889 caused by item 23 which asks about the relationship of the respondents with dyslexic students and it is stated the relationship is not very close. Although the mean value is the lowest, it indicates that respondents do not agree with the statement. Conclusively, there is no item that accepts a low mean value from the value of 2.000 and below. From the correlation test, it shows that there is a positive relationship with the coefficient value and that it is at a good level. This gives evidence that the more positive the attitude towards the dyslexic students, the better their academic performance.

The findings of this study are similar to those of Hanizah (2003) where she finds that there is a significant relationship between student's commitment in a subject with teacher's teaching practice in the subject. Another researcher named Razhiyah K.A (2005), also finds a correlation between the attitude and motivation of the students towards English Language as the outcome of the teaching with their achievement in that subject. Quality teachers are able to influence students' development and achievement in their studies.

Next, different quality of the teachers gives different effects to student's achievement. This is proven through the study by Culatta and Tompkins (1994) for different achievements between students taught by high quality teachers and students taught by low quality teachers three years in a row. 
Other than that, Rini (2012) in her study related to the effect of quality teachers towards student's achievement concludes that quality teaching also gives a greater impact than student's background. She states that the latter does not influence the subject at all but the main influence comes from his or her interactions with the teacher.

The conclusion that can be made from the correlation test finding is that teacher's attitude can enhance student's academic performance and this is supported by the work of Fredriksen and Rhodes (2004) where they state that the relationship between the teacher and students can leave an impact on student's learning and their academic achievement. They are also of the opinion that teacher's support will increase student's motivation to take part more actively in a subject, although initially they did not pay attention to the subject.

\section{Corresponding Author}

Associate Professor Dr. Md Nasir bin Masran, Faculty of Human Development, Sultan Idris Education University, 35900 Tanjong Malim, Perak, MALAYSIA.

Email:md.nasir@fpm.upsi.edu.my

\section{References}

Talib, A. R. B. (2006). Pengenalan Pendidikan Kanak-kanak Masalah Pembelajaran: Open University Malaysia (OUM). Kuala Lumpur: UNITEM Sdn.Bhd.

Salleh, A. M. (2003). Pendidikan Islam Falsafah, Sejarah Dan Kaedah Pengajaran Pembelajaran. Shah Alam: Fajar Bakti Sdn. Bhd.

Bender, W. M. (1995). Leaning Disabilitie; Characteristic, indentification and Strategies. Second Edition. Mass: A Simon \& Schusters Company.

Budiman Sdn. Bhd.

Tee, C. T., \& Boon, K. B. (1995). Pendidikan Khas Dan Pemulihan: Bacaan Asas.Kuala Lumpur: Dewan Bahasa dan Pustaka.

Chua, Y. P. (2006). Kaedah Penyelidikan. Malaysia: McGraw-Hill Education.

Darling-Hammond, L. (2000).Teacher Quality And Student Achievement: A Review Of State Policy Evidence. Education Policy Analysis Archives.ArizonaState: University. Volume 8 Number 1.

Meng. E. A. (1997). Psikologi Pendidikan II (Semester II). Shah Alam: Fajar Bakti Sdn. Bhd.

Affendi, F. B. (2014). Tahap Kepuasan Kerja dan Komitmen Organisasi Dalam Kalangan Guru

Kolej Volasional: Pendekatan Structural Equation model. Latihan IImiah UTHOM.

Ghafar, M. N. (1992). Penyelidikan Pendidikan. Skudai: Penerbit UTM.

Hamzah, H., \& Joy, N. (2008). Perkembangan Kanak-kanak .Kuala Lumpur: Kumpulan Budiman Sdn.Bhd.

Hallahan, D. P., \& Kauffman, J. M. (2000) Exceptional learners: Introduction to Pendidikan Khas Edisi Ketujuh. Boston: Allyn \& Bacon.

Kamis, H. (1993).Ujian Diagnostic dan Strategi Pengajian Kanak-kanak BermasalahPembelajaran: Latihan Ilmiah UKM. 
INTERNATIONAL JOURNAL OF ACADEMIC RESEARCH IN PROGRESSIVE EDUCATION AND

DEVELOPMENT

Vol. 8, No. 4, 2019, E-ISSN: 2226-6348 @ 2019 HRMARS

Jabatan Pendidikan Khas, Kementerian Pendidikan Malaysia, (2003). Buku Panduan Instrumen Penempatan Pendidikan Khas Bermasalah Pembelajaran (IPP): Manual. Selangor: Absolute Master Printers Sdn.Bhd.

Jamila, K. A. M. (2008). Pendidikan Khas Untuk Kanak-Kanak Istimewa.Edisi Pertama Bentong: PTS Profesional. Sdn.Bhd.

Husin, K. H. (1990). Pedagogi 2. Selangor: Longman Malaysia Sdn. Bhd.

Dewan, K. (2014). Kuala Lumpur: Dewan Bahasa dan Pustaka.

Kementerian Pendidikan Malaysia. (2003). Kurikulum Bersepadu Sekolah Rendah. Kuala Lumpur: Dewan Bahasa \& Pustaka.

Mohamad, K. (2011). Siri Pendidikan Guru Literasi Bahasa Melayu. Shah Alam: Fajar Bakti Sdn.Bhd. Lumpur: Dewan Bahasa dan Pustaka. 107-109.

Saad, M. B. M. (2013). Kesan Pendekatan Kognitif Tingkah Laku Dalam Kaunseling Kelompok Terhadap Kebimbangan Sosial Dan Perhatian Fokus Kendiri Remaja. Kuala Lumpur: Universiti Malaya.

Konting, M. M. (1990). Kaedah Penyelidikan Pendidikan. Kuala

Sang, M. S. (2003). Pendidikan di Malaysia. Kuala Lumpur: Kumpulan

Ashaari, O. (2001). Peranan, Tugas dan Tanggungjawab Guru di Sekolah .Kuala Lumpur: Utusan Publications \& Distributors Sdn Bhd.

Singh, R. K. J. (2010). Panduan Ilmu Pendidikan Komprehensif. Kuala Lumpur: Kumpulan Budiman Sdn.Bhd.

Razhiyah, K. A. (2005).Menjadi Guru Pendidikan Khas, Kuala Lumpur: PTS Profesional.

Sanders, W. L., \& Rivers, J. C. (1996). Cumulative and Residual Effects of Teachers of Future Students Academic Achievement. University of Tennessee Value: Added Research And Assessment Center.

Abdullah, C. Z. H., Daud, S. C., Ariff, N. Z. Z. M., \& Shaifuddin, N. (2018). Bibliographic Control and Resource Description Access Standard in Malaysia. International Journal of Academic Research in Progressive Education and Development, 7(3), 96-102.

Masran, M. N. Bin, Sengiah, S. L. A., Othman, R., \& Hassan, N. F. (2019). Attitude of Special Education Teachers In Teaching Special Education Integration Program Towards Learning Disabilities Students Dyslexia Academic Performances In Distrıct Hilir Perak, Perak. International Journal of Academic Research in Progressive Education and Development, 8(4), 977-987.

Usaini, M. I., \& Abubakar, N. B. (2015). The Impact of Parents' Occupation on Academic Performance of Secondary School Students in Kuala Terengganu. Multilingual Academic Journal of Education and Social Sciences, 3(1), 112-120.

Tyasari, I., Yusof, N. Z. M., Bahador, K. M. (2018). Indonesia's Participation in ASEAN Audit Regulators Group (AARG): Efficiency-driven or Institutional Pressure? International Journal of Academic Research in Accounting, Finance and Management Sciences 8 (3): 299-309. 